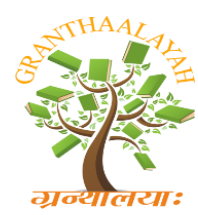

\author{
INTERNATIONAL JOURNAL OF
GRANTHAALAYAH \\ A knowledge Repository
}

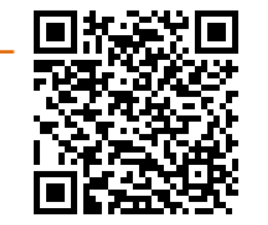

Science

\title{
YIELD PERFORMANCE AND ADAPTATION OF DESI CHICK PEA VARIETIES IN SELECTED DISTRICTS OF WOLAYTA AND HADIYA ZONES OF SOUTH ETHIOPIA
}

\author{
Yasin Goa ${ }^{1}$, Mathewos Ashamo ${ }^{2}$ \\ ${ }^{1,2}$ Areka Agricultural Research Center, P.O.Box 79, Areka, ETHIOPIA
}

\begin{abstract}
The experiments were conducted on station and on farm in three districts of Wolayta and Hadiya Zones, south region, Ethiopia, to evaluate the adaptation and yield, assess farmer's preferences of desi chick pea varieties to this agro ecological Zones during 2004/05 Meher Season. Data on plant height, hundred seed weight, pod per plant, days to flowering, days to maturity and grain yield were recorded. Five released varieties namely worku, Akaki, Mariye, Dubie, Dz-10-11 and local checks of respective locations were planted on $4.8 \mathrm{~m} 2$ plots at spacing of $30 \mathrm{~cm} * 10 \mathrm{~cm}$. The trials were laid in randomized complete block design with three replications. Twelve farmers from three districts at four villages' three farmers at each village were participated in conducting on farm trials with each farmer as a replicate. There were significant differences among varieties for grain yield and some of traits. The varieties Akaki and worku were superior yielded overall to the standard and local check across villages 'and on stations. Thus, Akaki and worku out yielded other varieties and had average yields of $1440.95 \mathrm{~kg} / \mathrm{ha}$ and $1434.75 \mathrm{~kg} / \mathrm{ha}$ at on station and similar trends on farm. The combined statistical analysis and farmers assessments revealed Akaki and worku out yielding other varieties which were also selected by farmers and researchers as the most preferred varieties'. It is therefore recommended that worku and Akaki which had higher yields be promoted for cultivation in the selected districts of south Ethiopia.
\end{abstract}

Keywords:

adaptation, chickpea, Desi, farmer's preferences, on farm evaluation, released varieties, yield.

Cite This Article: Yasin Goa, and Mathewos Ashamo, "YIELD PERFORMANCE AND ADAPTATION OF DESI CHICK PEA VARIETIES IN SELECTED DISTRICTS OF WOLAYTA AND HADIYA ZONES OF SOUTH ETHIOPIA" International Journal of Research - Granthaalayah, Vol. 4, No. 3 (2016): 33-41.

\section{INTRODUCTION}

Chickpea (Cicerarietinum L.) is the second most important pulse crop with 11.2 million cultivated areas in the world (Anonmyous, 2006). It is a cool-season annual pulse crop that is grown in tropical, subtropical, and temperate regions of the world (Muehlbauer and Tulu, 1997). 
Most production and consumption of chickpea (95\%) takes place in developing countries. Chickpea (Cicer arietinum) is Ethiopia's most important pulse crop widely grown in highland and semi-highland regions of the country mainly on clay soil. It was grown on an area of 200,066.05 hectares of land annually with a production of 2,538,713.21 qt in Ethiopia (CSA, 2006/7). It is also an excellent source of human and animal food and also plays an important role in the maintenance of soil fertility, particularly in the dry, rain fed areas (Katerji etal, 2001) and it fixes Rhzobium bacteria on roots(Akcin,1988). The chick pea plant and its straw are used as forage, hay and silage in the vertisol soils of Ethiopian highlands. Previous livestock feeding experiments have been carried out in another place show chickpea to be a good source of protein for feeds, except that the amino acids methionine and cystine are deficient. Besides, similar to other pulse crops it is a good rotational crop and thus improves soil fertility.

Chick pea is produced in various zones, some special woredas and pocket areas in the Southern Nations, Nationalities and Peoples Regional State (SNNPRS), south Ethiopia. In general, in this region chick pea occupies about 4,536.02 hectares of land annually with estimated production of 29,034.52 quintals (CSA, 206/7). The national average yield of chick pea in Ethiopia is 12.69 $\mathrm{qt} / \mathrm{ha}$ and the regional average yield of $6.4 \mathrm{qt} / \mathrm{ha}$, which is by far below the potential yield. The reasons for low yields in the region include lack of improved chick pea varieties, resistance to a biotic and biotic stresses. Past researches' in the country and elsewhere indicated that chick pea varieties produce significantly yields at different locations emphasizing to evaluate chick pea varieties in various agro ecological zones for their adaptation, yield potential and disease reaction so as to select appropriate varieties for promotion on farmers' field. Geletu Bejiga and Yadeta Anbessa (1992/93) evaluated 112 and 373 desi chick pea entries at Debrezeit Agricultural Research center and suggested that wide range variability existed among their chick pea lines for seed yield/ plant, plant height, days to flowering, days to maturity, root rot, wilt and pod borer. They stated that among those genotypes 52 entries that had good plant stand and showed high level of resistant to wilt were selected and also noted that those entries showed inferior as performance as compared to exotic material were discarded. Even though there were some research efforts to bridge the big gap between actual and potential yield in the chick pea is the result of mainly lack of adoption of improved production packages.

In general the production of chick pea all year round basis in all parts of Ethiopia is expected to increase production, thereby improve nutrition, contributes to food security as well as income of the producers. Therefore, the objectives of this study were to evaluate chick pea varieties in three districts of four villages and two stations with a view to selecting and recommending the variety (ies) that will best adapt to the conditions and assess farmer's preferences in the southern parts of Ethiopia.

\section{MATERIALS AND METHODS}

The study was carried out both at on station and on farm. The on station study was conducted at the South Ethiopia Agricultural Research Institutes of Areka regional Research center at Hossana and Jewi stations. The altitudes, annual rain fall, soil types of the study site are 2290mas.1, 1592.1mm, Profondic Luvisols for Hossana and 1900-2100masl, 1400-1600 mm, clay soil for Jewi station, respectively. The study involved testing of the total of five improved and local varieties for adaptation and yield performance. The trials were laid in randomized complete 
block design with three replications. The trial was planted at Hossana and Jewi stations at four rows with plot area of $4.8 \mathrm{~m}^{2}$ of $4 \mathrm{~m} * 1.2 \mathrm{~m}$ during the Meher season of 2004/05. The crop was planted in mid to late august at a spacing of $30 \mathrm{~cm} * 10 \mathrm{~cm}$. One variety Dz-10-11 and local check were used as checks at both sites. Hand weeding was used to control weeds as per recommendation. Data on plant height, hundred seed weight, pod per plant, days to flowering, days to maturity and yield were recorded. Data on grain yield in gram per plot were collected and changed into $\mathrm{kg} / \mathrm{ha}$. The harvesting and threshing of the plant were done manually.

On-farm chick pea varieties yield performance and adaptation trials were conducted in the Lemu, Offa and Damot Gale districts of the Hadiya and Wolyta Zone of South Region, Ethiopia during 2004/05 meher season. Two villages Jewi and Bobicho were located in the Lemu district, one village Gacheno in the Damot gale district and one village Mancha gogara in the Offa district for a total of four villages in three districts. The soil texture ranged from sandy loam-clay loam at Bobicho and Jewi on farm and black clay for both Mancha gogara of Offa district and Gacheno kebele of Damot Gale district. The trial comprised all the five improved varieties that were obtained from the Debrezeit agricultural Research and local checks of respective locations were included and the farmers of the study site were aware of Desi type chick pea production. Varieties Dz-10-11 (standard check), a local landrace check, worku, Akaki.Mariye and Dubie were planted in a randomized complete block design with three replications; an individual farm was considered a complete block. A total of 12 farmers, three farmers at each village were selected and planting started in late August and continued until early September, in 2004/05. Each plots comprised of four rows which were $4 \mathrm{~m}$ long. Spacing of $30 \mathrm{~cm}$ between rows and 10 $\mathrm{cm}$ between plants was used. Trials were managed according to recommended agronomic practices.

Matrix ranking was used to assess farmers' opinion and perceptions on the varieties. To reveal farmers preferences on chick pea varieties, a total of 80 farmers (12 host and 68 non host farmers) at four villages; 20 farmers ( 3 host and 17 non host) at each village were selected and focus group interviews' were held with group of farmers to obtain their perceptions on the chick pea varieties under evaluation. Therefore, selected 20 farmers at each village were invited to visit the trial site at pod filling, maturity stage, at harvest and farmers were asked for their perceptions on the chick pea varieties under evaluation based on the specific criteria of yield, number of branch, pod length, maturity, seed color, seed size, number of seed per pod, pod number and taste.

A scale of 1-5 was used to assess these traits with the definition as follows: $5=$ not preferred, $4=$ less preferred, $3=$ moderately preferred, $2=$ highly preferred and $1=$ excellent. Farmers were asked to place 1, 2, 3, 4 or 5 for variety ranking representing a given trait and variety according to the above scales. The Researchers were prepared chick pea varieties rating sheet indicating these criteria and farmers were asked by Researchers to give their preference by ranking the six varieties under evaluation. Farmers' responses were counted to get totals for each trait per variety; the smallest total count was assigned first rank. In addition to technical support; researcher also provides seed and chemicals for pest control to farmers. Farmers provide land and labour for crop management. Data was collected for plant height, pod per plant, hundred seed weight, days to flowering, days to maturity and grain yield per hectare. Data collected were 
subjected to ANOVA and the treatments means were separated with the Duncan's Multiple Range Test (DMRT) using SAS (2010).

\section{RESULTS AND DISCUSSIONS}

The data available revealed that differences among varieties were significant for yield, plant height, number of pods, hundred seed weight (Table $1 \& 2$ ). These findings are in agreement with Ines C. Gonzales and Fernando R. Gonzales (2014) who reported considerable variation in the grain yield, number of pod, hundred seed weight and plant height of different chick pea varieties when planted under various environments. The days to flowering and maturity this showed no significant differences among the varieties (Table $1 \& 2$ ). This results are in contrast with the findings of Ines C. Gonzales and Fernando R. Gonzales (2014) who noted that the effect of the different varieties used across locations on days to flowering and days to maturity were significant. Days to flowering ranged from 44.7 days to 48 days for Hossana and 44.67 to 47 days to Jewi stations, respectively. The day's differences to flowering between earlier and latest flowered variety varies from 2.3-3.3 days. All genotypes were matured between 127 day and 136.7 days. Plant height ranged from $27.7 \mathrm{~cm}$ to $37.7 \mathrm{~cm}$. These results are in line with Bicer B. Tuba, Yilmaz Abdurahim, 2013 revealed that, in 37 chick peas germplasm at Diy Arbaki, Turkey days to flowering ranged from 57 to 73 days, and days to maturity varied from 97 to 105 days. He also noted that plant height varied from 27 to $39 \mathrm{~cm}$. Number of pod per plant ranged from 55 to 75.3 for Hossana and 48.3 to 63.7 for Jewi stations. Number of pods per plant varied from 3.2 to 12.9 pods (Bicer B. Tuba, Yilmaz Abdurrahman, 2013) and number of pods per plant ranged from 1.0 to 15.0 in genotypes from ICARDA (Canci and Toker ,2009). Another yield component measured was hundred seed weight. The varietal effect on the hundred seed weight was significant $(\mathrm{P}<0.05)$ at both stations and the results (Table-2) indicated that the maximum hundred seed weight (16.7 $\mathrm{gm}$ and $18.7 \mathrm{gm}$ ) were recorded in variety Mariye, followed by varieties worku and Akaki with ( $18.6 \mathrm{gm} ; 17.3 \mathrm{gm})$ and (16 gm;16.6 gm) at Hossana and Jewi, respectively (Table 2).Variety Mariye had the highest hundred seed weight followed by worku and Akaki at both station whereas cultivar Dz-10-11 and local had the lowest.

Grain yield ranged from $923.6 \mathrm{~kg} / \mathrm{ha}$ to $1444.4 \mathrm{~kg} / \mathrm{ha}$ at Hossana and from 930.5 to 1438.9 at Jewi stations. Akaki and worku were recorded as high yielding varieties. Minimum grain yield was obtained from Dubie, Dz-10-11 and local check. Bicer B. Tuba, Yilmaz Abdurrahman (2013) reported that grain yield ranged from $315 \mathrm{~kg}$ ha-1 to $2273 \mathrm{~kg} / \mathrm{ha}$ by average $1256 \mathrm{~kg} / \mathrm{ha}$. Two varieties (Akaki and worku) had higher grain yield than the local and standard check and also there was no significant yield differences between them at both study sites.

On farm: - Analysis of variance revealed that differences among varieties were significant $(\mathrm{P}<0.05)$ to highly significant $(\mathrm{p}<0.01)$ for grain yield (Table 1$)$. The grain yield was significantly different in varieties tested in this experiment and the maximum grain yield $(1401.75 \mathrm{~kg} / \mathrm{ha})$ was recorded in variety Akaki, while worku produced average grain yield of $1308 \mathrm{~kg} / \mathrm{ha}$ (Table 3). The local and standard check gave lower yield $817.7 \mathrm{~kg} / \mathrm{ha}$ and 892.4 $\mathrm{kg} / \mathrm{ha}$. The results of on station and on-farm managed trials revealed significant $(\mathrm{P}<0.05)$ to highly significant differences $(\mathrm{p}<0.01)$ among varieties (Table 3$)$. The superior and farmers preferred varieties Akaki and worku showed chance of wider dissemination to the farmers in the study area. According to Gowda et al., 2000 farmers usually adapt varieties that yield more than 
their locally adapted cultivars; and meet the preferred traits which differ from one community to another.

Gowda et al., 2000 on finger millet and Assefa et al 2005 on beans reported that high yield and acceptable varieties characteristics have shown significant adoption which resulted to subsequent crop improvements in Ethiopia and elsewhere. In the present study show the yield advantage of $9.24 \%$ was recorded (Table 3) between on-station and on-farm environments clearly indicates the inconsistent yields obtained by most farmers in Ethiopia. These results are in agreement with Assefa et al., 2005 in Ethiopia and Tulole etal, 2008 findings in Tanzania who reported the big yield advantage between on-station and on-farm environments were observed by most farmers in sub-Saharan Africa. The superior yielding varieties Akaki and Worku produced $1401.75 \mathrm{~kg} / \mathrm{ha}$, $1308 \mathrm{~kg} / \mathrm{ha}$ of grain yield, (71\%) and (37\%) more than the local check, respectively at on farm trials (Table 3). These results are further supported by Tulole etal, 2008 who reported that the superior varieties have grain yield advantage of about $(68.5 \%)$ and $(38.5 \%)$ more than the local check (Mamboleo), at on farm trials, respectively. Similarly over two stations $39 \%$ and $38 \%$ more than local check was recorded by these top yielding varieties.

The average grain yield from the four on farm sites ranged $817.7 \mathrm{~kg} / \mathrm{ha}$ for the variety Dz-10-11 to $1401.8 \mathrm{~kg} / \mathrm{ha}$ for variety Akaki (Table 3). Akaki and worku performed relatively better than others in all the villages. All the test varieties showed relatively lower performance in Jewi village than in the rest study villages. This might be due to poor management by farmers.

At Bobicho on farm, varieties Akaki and worku yielded significantly higher than both the standard check and local checks. The local check yielded significantly lower. The yield range from 756.9 to $1358.3 \mathrm{~kg} / \mathrm{ha}$ for this site and showed similar trends observed in Jewi village, varieties Akaki and worku out yielded the standard and local checks whereas the differences between them were not statistically significant.

Similar, in Gacheno village, significant yield difference was observed among varieties Akaki, work and the rest of varieties. However the differences among them were not statistically significant. These findings are in agreement with Kenea Yadeta (2001) who on analyzing on farm study developed technology, two improved chick pea varieties (worku and Akaki) and local at two seed rate in three districts during two cropping seasons. He found that in overall statistical and economically rating both improved varieties were preferred to local variety. These yields indicate with proper selection of varieties it is possible for farmers to achieve better yields and improved production packages.

\section{FARMERS' PERCEPTION ON THE PREFERENCE OF THE DESI CHICK PEA VARIETIES}

Abebe etal, 2005 reported that farmers have their own selection criteria for new varieties which largely depend on the importance of the crop in the farming system and uses. The ranking of chick pea varieties based on the perception of the farmers are presented in Table 4. As per the selection criteria set farmers ranked Akaki and worku either at the first or the second position across all three districts of four villages (Table 4). The overall preference ranking of varieties based on nine criteria was in the order Akaki, worku, mariye, Dubie, Local and Dz-10-11, 
respectively. Farmers prefer cultivars that meet multiple objectives; on sorghum (Mekbib, 2006; Tulole etal, 2010); on ground nut (Tulole etal, 2008). This means that in present study Akaki and worku newer improved cultivars could easily be introduced and incorporated in the farming systems based on various subjective preference criteria. Farmers preferred the variety Mariye thirdly as it produced attractive seed size and yield, whereas Dz-10-11 and local check were ranked the lowest.

\section{CONCLUSION}

Five chickpea varieties and local checks of respective locations were tested for yield and adaptation in selected districts of south region, Ethiopia. Differences among varieties were significant for grain yield and some of traits. Varieties Akaki and worku were visually selected by the farmers as good for grain yield and this study indicated that proper choice of varieties with improved management can boost farmers' yields to double. From this study, it showed that Akaki and worku varieties had the highest yields over others evaluated. Thus, observing the yield, researchers and farmer's perception, it can be recommended that Akaki and worku which had comparably highest yields be adopted for cultivation in the selected districts of Wolayata and Hadiya Zones in Southern Ethiopia.

\section{REFERENCES}

[1] Abebe G,AssefaT.harrun H.,Mesfin T.,Al-tawaha AM(2005).Participatory selection of drought tolerant maize varieties using mother and baby methodology: case study in the semi arid zones of the centeral rift valley of Ethiopia. World J.Agri.Scie.1:22-27.

[2] Akcin A (1988). Edible pulses publications of Agril.Faculty of selcuk university No:8 konya-Turkey(in Turkish).

[3] Anonymous (2006). FAO web page(WWW.fao.org)

[4] Assefa T, Abebe G, Fininsa C, Tesso B, Al-Tawaha ARM (2005) Participatory bean breeding with women and small holder farmers in eastern Ethiopia. World J. Agric. Sci. 1: 28-35.

[5] Bicer B.T., Toncer O., 2012. Plant populations' densitiesand seed size interaction in chickpea (CicerarietinumL.). Selcuk Tarimve GidaBil. Der., 26 (2), p. 18-24.

[6] Canci H., Toker C., 2009. Evaluation of Yield Criteriafor Drought and Heat Resistance in Chickpea (CicerarietinumL.). J. Agronomy \& Crop Science. 195, p.47-54.

[7] CSA (Central Statistical Authority of Ethiopia) 2006/7. Agricultural sample survey meher season 2006/7: Statistical report on area and production of crops, farm management practices, farm implements, machineries and storage mechanisms. Addis Ababa, Ethiopia.

[8] Geletu Bejiga and YadetaAnbessa 1992/93. Nile valley regional program on cool season food legumes: Annual Repor, Evaluation of local and exotic desi chick pea germplasm for adaptation to the mid and highlands areas. Addis Ababa, Ethiopia.Pp.106-107

[9] Gowda BTS, Halaswamy BH, Seetharam A, Virk DS, Witcombe JR (2000). Participatory approach in varietal improvement: A case study in finger millet in India. Curr. Sci. 79: 366-368.

[10] Ines C. Gonzales and Fernando R. Gonzales.2014.Yield Performance of Chickpea (Cicer 
arietanumL.) Varieties across Locations of the Philippines Cordillera Region. International Journal of Scientific \& Engineering Research, Volume 5, Issue 3, March2014 ISSN 2229-5518.pp. 1548-1554.

[11] Katerji N,Van Hoorn JW,Hamdy A,Mastrorilli M,Owies T,Malhotra Rs(2001).Response to soil salinity of chick pea varieties differing in drought tolerance. Agri.water mange, 50:83-96

[12] KeneaYadeta (2001). On farm Analysis of Improved chick pea production technologies in East shoa,Ethiopia.In:in The proceeding of the 10th conference of the crop society of Ethiopia. Addis Ababa, Ethiopia between 19th and 21st June 2001.Pp.215-223.

[13] Mekbib, F. (2006).Farmers and formal breeding of sorghum (sorghum bicolor (L.)Moech) and the implication for integrated plant breeding .Euphytica 152,163-176.

[14] Muehlbauer F.J., Tullu A. 1997. CicerarietinumL.New Crop Fact SHEET. Center for New Crops \& Plant Products, Purdue Univ

[15] Tulole L.Bucheyeki, Erasto M.Shenkalwa, Theofora X.Manpunda, Leah W.Matata.2008. On farm evaluation of promising ground nut varieties for adaptation and adoption in Tanzania. African Journal of Agricultural Research, University of Kwazulu-Natal, South Africa. Academic journals, vol.3,No.8,pp.531-536

[16] Tulole L.Bucheyeki, Erasto M.Shenkalwa, Theofora X.Manpunda,Leah W.Matata.2010. yield performance and adaptation of four sorghum cultivars in Igunga and Nzega districts of Tanizania.International Journal of the Faculty of Agriculture and Biology, Warsaw university of life sciences, Poland. Communication in Biometry and crop scinece,vol.5,No.1,pp.4-40

\section{APPENDIX}

Table 1: Analysis of variance of six Desi chick pea genotypes at individual locations during 2004/05 meher season

\begin{tabular}{|c|c|c|c|c|c|c|c|}
\hline \multirow[b]{3}{*}{ S.V } & \multirow[b]{3}{*}{ DF } & \multicolumn{2}{|c|}{ Grain yield $(\mathrm{kg} / \mathrm{ha})$ on station trials } & \multicolumn{4}{|c|}{ Grain yield $(\mathrm{kg} / \mathrm{ha})$ on farm trials } \\
\hline & & Hossana & Jewi & Jewi & Bobicho & Gacheno & Offa \\
\hline & & Mean Square & Mean Square & Mean Square & Mean Square & Mean Square & Mean square \\
\hline REP & 2 & $497793.28 *$ & $375996.3 *$ & $487617.59 *$ & $491274.11^{*}$ & $279707.75^{*}$ & $430411.84 *$ \\
\hline VAR & 5 & $140619.59 *$ & $162286.26^{* *}$ & $113487.1^{*}$ & $168480.13^{* *}$ & $166965.27 *$ & $258091.24 *$ \\
\hline Error & 10 & 1500.54 & 7360.92 & 10524.69 & 14988.23 & 22589.69 & 26002.12 \\
\hline $\mathrm{CV}$ & & 10.23 & 7.41 & 10.32 & 11.55 & 12.94 & 14.72 \\
\hline $\begin{array}{l}\text { LSD } \\
(5 \%)\end{array}$ & & 222.8 & 156.1 & 131.97 & 222.73 & 193.35 & 293.36 \\
\hline G. $m$ & & 1196.75 & 1157.41 & 993.29 & 1059.95 & 1161.1 & 1095.6 \\
\hline
\end{tabular}

Note: - G.m= Grand mean S.V =Source of variation ns, **, * are non-significant, significant $(\mathrm{P}<0.05)$ and highly Significant $(\mathrm{P}<0.01)$, respectively.

Table 2: Mean number of pod per plant, hundred seed weight $(\mathrm{gm})$, plant height $(\mathrm{cm})$, days to flowering, days to maturity and grain yield (kg/ha) per Desi chick pea varieties at Hossana and Jewis station in 2004/05 meher season

\begin{tabular}{|l|l|l|l|l|l|l|}
\hline Chick pea varieties & & & & \\
\cline { 1 - 6 } Hossana on station & Yield(kg/ha) & Hsw $(\mathrm{gm})$ & Plant height $(\mathrm{cm})$ & Pod/plant & FD & MD \\
\hline worku & $1430.6 \mathrm{a}$ & $18.6 \mathrm{a}$ & $37.6 \mathrm{a} 2$ & $73.7 \mathrm{a}$ & $46 \mathrm{a}$ & $127 \mathrm{a}$ \\
\hline Akaki & $1444.4 \mathrm{a}$ & $17.3 \mathrm{a}$ & $37.7 \mathrm{a}$ & $75.3 \mathrm{a}$ & $45.67 \mathrm{a}$ & $134.7 \mathrm{a}$ \\
\hline Mariye & $1262.5 \mathrm{ab}$ & $18.7 \mathrm{a}$ & $37.3 \mathrm{a}$ & $61 \mathrm{~b}$ & $46.3 \mathrm{a}$ & $131.3 \mathrm{a}$ \\
\hline
\end{tabular}




\begin{tabular}{|l|l|l|l|l|l|l|}
\hline Dubie & $923.6 \mathrm{c}$ & $12.7 \mathrm{~b}$ & $27.7 \mathrm{c}$ & $59.7 \mathrm{~b}$ & $48 \mathrm{a}$ & $129.3 \mathrm{a}$ \\
\hline DZ-10-11 & $1029.2 \mathrm{c}$ & $14 \mathrm{~b}$ & $30.7 \mathrm{bc}$ & $58.3 \mathrm{~b}$ & $47.33 \mathrm{a}$ & $136.7 \mathrm{a}$ \\
\hline Local check & $1090.3 \mathrm{bc}$ & $14.7 \mathrm{a}$ & $34.3 \mathrm{ab}$ & $55 \mathrm{~b}$ & $44.7 \mathrm{a}$ & $130 \mathrm{a}$ \\
\hline Grand mean & 1196.8 & 16 & 34.22 & 63.8 & 46.3 & 131.5 \\
\hline CV & 10.23 & 8.22 & 8.66 & 6.31 & 7.1 & 4.67 \\
\hline LSD $(5 \%)$ & 222.8 & 2.39 & 5.39 & 7.33 & 5.99 & 11.2 \\
\hline Jewi on station & & & & & & \\
\hline Chick pea varieties & Yield(kg/ha) & Hsw (gm) & Plant height $(\mathrm{cm})$ & Pod/plant & FD & MD \\
\hline worku & $1437.5 \mathrm{a}$ & $16 \mathrm{ab}$ & $33.7 \mathrm{a}$ & $63.7 \mathrm{ab}$ & $46.3 \mathrm{a}$ & $128.3 \mathrm{a}$ \\
\hline Akaki & $1438.9 \mathrm{a}$ & $16.6 \mathrm{a}$ & $33.5 \mathrm{a}$ & $64 \mathrm{a}$ & $45.3 \mathrm{a}$ & $130 \mathrm{a}$ \\
\hline Mariye & $1172.2 \mathrm{~b}$ & $16.7 \mathrm{a}$ & $33.6 \mathrm{a}$ & $55.3 \mathrm{bc}$ & $44.67 \mathrm{a}$ & $128.67 \mathrm{a}$ \\
\hline Dubie & $986.11 \mathrm{c}$ & $14 \mathrm{bc}$ & $31 \mathrm{a}$ & $51.3 \mathrm{c}$ & $46 \mathrm{a}$ & $129 \mathrm{a}$ \\
\hline DZ-10-11 & $930.5 \mathrm{c}$ & $12.6 \mathrm{c}$ & $30.57 \mathrm{a}$ & $48.3 \mathrm{c}$ & $45 \mathrm{ab}$ & $127 \mathrm{a}$ \\
\hline Local check & $979.2 \mathrm{c}$ & $13.3 \mathrm{c}$ & $30.67 \mathrm{a}$ & $50.3 \mathrm{c}$ & $47 \mathrm{a}$ & $128.4 \mathrm{a}$ \\
\hline Grand mean & 1157.41 & 14.9 & 32.22 & 55.5 & 45.7 & 128.6 \\
\hline CV & 7.41 & 9.06 & 7.72 & 8.55 & 4.22 & 2.9 \\
\hline LSD(5\%) & 156.09 & 2.45 & 4.53 & 8.64 & 3.5 & 6.79 \\
\hline
\end{tabular}

Means within each column followed by the same letter are not significantly different at $5 \%$ as determined by

Duncan's Multiple Range Test NB:-Hsw=Hundred seed weight, FD=Days to Flowering \& MD=Days to maturity

Table 3: Mean grain yield (kg/ha) per Desi chick pea varieties at Hoassa and Jewi on station and at Gacheno, Offa/Manchagogara, Bobicho and Jewi on farm in 2004/05 meher season

\begin{tabular}{|c|c|c|c|c|c|c|c|c|c|c|}
\hline \multirow{2}{*}{$\begin{array}{ll}\text { Chick } & \text { pea } \\
\text { varieties } & \end{array}$} & \multicolumn{4}{|c|}{ Yield(kg/ha) of on station trials } & \multicolumn{5}{|c|}{ Yield(kg/ha) of on farm trials } & \multirow[b]{2}{*}{ Y.A \% } \\
\hline & Hossana & Jewi & Mean & Y.A\% & Gacheno & Offa & Bobicho & Jewi & Mean & \\
\hline worku & $1430.6 \mathrm{a}$ & $1437.5 \mathrm{a}$ & 1434.75 & $39 \% 1 \mathrm{c}$ & $1380.6 \mathrm{a}$ & $1298.6 \mathrm{ab}$ & $1305.6 \mathrm{ab}$ & $1247.2 \mathrm{a}$ & 1308 & $37 \% \mathrm{lc}$ \\
\hline Akaki & $1444.4 \mathrm{a}$ & $1438.9 a$ & 1440.95 & $38 \% \mathrm{lc}$ & $1480.6 \mathrm{a}$ & $1568.1 \mathrm{a}$ & $1358.3 \mathrm{a}$ & $1200 \mathrm{a}$ & 1401.75 & $71 \% \mathrm{lc}$ \\
\hline Mariye & $1262.5 \mathrm{ab}$ & $1172.2 \mathrm{~b}$ & 1217.35 & & $1204.2 \mathrm{ab}$ & $1100.0 \mathrm{bc}$ & $1095.8 \mathrm{bc}$ & $986.11 b$ & 1096.528 & \\
\hline Dubie & $923.6 \mathrm{c}$ & $986.11 \mathrm{c}$ & 954.855 & & $1030.6 \mathrm{bc}$ & $933.3 \mathrm{~cd}$ & $925 \mathrm{~cd}$ & $905.6 \mathrm{bc}$ & 948.625 & \\
\hline DZ-10-11 & $1029.2 \mathrm{c}$ & $930.5 \mathrm{c}$ & 979.85 & & $995.8 \mathrm{bc}$ & $784.7 \mathrm{~d}$ & $918.1 \mathrm{~cd}$ & $870.8 \mathrm{bc}$ & 892.35 & \\
\hline Local check & $1090.3 \mathrm{bc}$ & $979.2 \mathrm{c}$ & 1034.75 & & $875 c$ & $888.9 \mathrm{~cd}$ & $756.9 \mathrm{~d}$ & $750 \mathrm{c}$ & 817.7 & \\
\hline Grand mean & 1196.8 & 1157.41 & 1177.1 & $9.24 \%$ & 1161 & 1095.6 & 1059.95 & 993.3 & 1077.5 & \\
\hline $\mathrm{Cv}$ & 10.23 & 7.41 & & & 12.94 & 14.71 & 11.55 & 10.32 & & \\
\hline LSD (5\%) & 222.8 & 156.09 & & & 273.4 & 293.4 & 222.7 & 186.6 & - & \\
\hline
\end{tabular}

Note:- Y.A=Yield advantage,lc=Local check

Table 4: Matrix ranking of Desi chick pea varieties across four villages in lemu, Damot Gale and Offa districts

\begin{tabular}{|l|l|l|l|l|l|l|l|l|l|l|l|}
\hline Chick pea varieties & \multicolumn{9}{|c|}{ Selection Criteria's } \\
\hline Jewi on farm & yield & Nb & Pod length & mat & sc & Sz & spp & ppo & Ts & Total & Rank \\
\hline Worku & 3 & 1 & 2 & 2 & 1 & 2 & 3 & 2 & 2 & 18 & $\mathbf{1}^{\text {st }}$ \\
\hline Akaki & 2 & 3 & 2 & 2 & 1 & 2 & 2 & 3 & 2 & 19 & $\mathbf{2}^{\text {nd }}$ \\
\hline Mariye & 3 & 2 & 2 & 3 & 2 & 1 & 2 & 3 & 2 & 20 & $\mathbf{3}^{\text {rd }}$ \\
\hline Dubie & 4 & 4 & 3 & 2 & 2 & 3 & 2 & 3 & 2 & 25 & $4^{\text {th }}$ \\
\hline Dz-10-11 & 4 & 3 & 3 & 3 & 3 & 4 & 3 & 4 & 3 & 30 & $6^{\text {th }}$ \\
\hline Local check & 4 & 3 & 3 & 3 & 3 & 2 & 3 & 3 & 3 & 27 & $5^{\text {th }}$ \\
\hline 2.Bobicho on farm & & & & & & & & & & & \\
\hline Worku & 3 & 1 & 4 & 2 & 2 & 2 & 3 & 2 & 2 & 21 & $\mathbf{2 r d}^{\text {rd }}$ \\
\hline Akaki & 2 & 2 & 2 & 2 & 2 & 2 & 2 & 3 & 2 & 19 & $\mathbf{1}^{\text {st }}$ \\
\hline Mariye & 3 & 2 & 2 & 3 & 2 & 1 & 3 & 3 & 3 & 22 & $3^{\text {rd }}$ \\
\hline Dubie & 4 & 4 & 3 & 2 & 2 & 3 & 2 & 2 & 2 & 24 & $4^{\text {th }}$ \\
\hline Dz-10-11 & 4 & 3 & 4 & 3 & 3 & 2 & 3 & 3 & 3 & 28 & $6^{\text {th }}$ \\
\hline Local check & 3 & 3 & 3 & 3 & 3 & 2 & 3 & 3 & 3 & 26 & $5^{\text {th }}$ \\
\hline
\end{tabular}




\begin{tabular}{|l|l|l|l|l|l|l|l|l|l|l|l|}
\hline 3.Gacheno on farm & & & & & & & & & \\
\hline Worku & 2 & 1 & 3 & 2 & 1 & 2 & 3 & 2 & 2 & 18 \\
\hline Akaki & 1 & 2 & 2 & 2 & 1 & 2 & 2 & 3 & 2 & 17 \\
\hline Mariye & 3 & 2 & 2 & 3 & 2 & 1 & 3 & 3 & 3 & 22 \\
\hline Dubie & 3 & 4 & 3 & 2 & 2 & 3 & 2 & 2 & 2 & 23 & $\mathbf{1}^{\text {nd }}$ \\
\hline Dz-10-11 & 4 & 3 & 4 & 3 & 3 & 2 & 3 & 3 & 3 & 28 \\
\hline Local check & 3 & 3 & 4 & 3 & 3 & 4 & 3 & 3 & 3 & 29 \\
\hline 4.Offa on farm & & & & & & & & & $5^{\text {th }}$ \\
\hline Worku & 2 & 1 & 3 & 2 & 2 & 2 & 3 & 2 & 2 & 19 \\
\hline Akaki & 2 & 2 & 2 & 2 & 1 & 2 & 2 & 3 & 2 & 18 \\
\hline Mariye & 3 & 2 & 2 & 2 & 2 & 2 & 3 & 2 & 2 & 20 \\
\hline Dubie & 4 & 4 & 3 & 2 & 2 & 3 & 2 & 2 & 2 & 24 \\
\hline Dz-10-11 & 4 & 3 & 4 & 3 & 3 & 2 & 3 & 3 & 3 & 28 \\
\hline Local check & 3 & 3 & 3 & 3 & 3 & 2 & 3 & 3 & 3 & 27 \\
\hline
\end{tabular}

Key: yield=high yielding, $\mathrm{Nb}=$ number of branches, $\mathrm{Pl}=$ pod length, mat $=$ maturity, $\mathrm{Sz}=\mathrm{seed}$ size, $\mathrm{sppo}=\mathrm{seed}$ number, $\mathrm{Sc}=$ seed color, $\mathrm{ppo}=$ pod number per plant and $\mathrm{Ts}=$ taste - preference scale $1-5$, Higher preferences $=1$, to lower preference $=5$ 